\title{
Review: Sugarcane production: Impact of climate change and its mitigation
}

\author{
ASHOK K. SRIVASTAVA ${ }^{1}$, MAHENDRA K. RAI ${ }^{2, \bullet}$ \\ ${ }^{1}$ Department of Geology, Sant Gadge Baba Amravati University, Amravati 444602, Maharashtra, India. Tel: +91-721-2662207/8, Extension-302. Fax: \\ +91 721 2660949, 2662135.email: ashokamt2000@hotmail.com \\ ${ }^{2}$ Department of Biotechnology, Sant Gadge Baba Amravati University, Amravati 444602, Maharashtra, India. Tel: +91-721-2662207/8, Extension-267. \\ Fax: +91 721 2660949, 2662135. 'email: pmkrai@ hotmail.com
}

Manuscript received: 11 August 2012. Revision accepted: 17 October 2012.

\begin{abstract}
Srivastava AK, Rai MK. 2012. Review: Sugarcane production: impact of climate change and its mitigation 13: 214-227. Sugarcane is a climatic sensitive crop: therefore, its spatial distribution on the globe is restricted as per the suitability of various climatic parameters. The climate change, though, a very slow phenomenon is now accelerated due to natural, as well as enormous human activities disturbing the composition of atmosphere. The predications of various climatic models for probable rise in temperature, rainfall, sea level show an alarming condition in forthcoming decades. As the sugarcane is very sensitive to temperature, rainfall, solar radiations etc. therefore, a significant effect on its production and sugar yield is expected in future. It is also well known that sugarcane is one of the precious crops of the world and its end products i.e. sugar and ethanol have a continuous growing demand on global level. Hence, the studies related to good production of sugarcane in changing conditions of climate has become one among the front line area of research and is a major concern of scientist's world over. Advance agronomic measures including development of suitable cane varieties susceptible to changed climatic conditions, land preparation, time and pattern of plantation, weed, disease and pest managements, nutrients managements, proper timing and adequate water management seems to be the affective measures for obtaining high production of crop with good quality juice in future.
\end{abstract}

Key words: sugarcane, climate change, agronomy, soil

\section{INTRODUCTION}

Sugarcane, a taxa represented by stout, jointed, fibrous stalk of 2-6 $\mathrm{m}$ with sugar is a tall perennial grass of the genus Saccharum of family Poaceae (Clark et al. 1995). It is native to warm temperate to tropical regions of South Asia and Southeast Asia having humid climate. This C4 plant has a high efficiency to store solar energy as well as efficient converter of the same. Broadly, four growth phases of the plant can be identified, i.e. germination phase, tillering phase, main growth phase and, maturity and ripening phase. The first phase covers a period of planting up to the completion of germination of buds which depends upon field condition and lasts for 4-5 weeks. The optimum temperature for sprouting is around $20-30^{\circ} \mathrm{C}$. The second phase is of about 120 days i.e. tillering which is a tender and highly sensitive to the local climate, soil climate, water and nutrient supply as it forms a base for good production. Temperature and solar radiations play a major role in this phase. Temperature around $30^{\circ} \mathrm{C}$ is optimum whereas: sufficient light is required for good growth. Tillering is also influenced by water availability, spacing manuring, weed control etc. The phase of main growth is a period of actual cane formation and elongation which may take 270-300 days. Better growth of the cane requires warm and humid conditions which facilitates leaf production and their growth. Similar temperature condition as of the second phase with around $80 \%$ humidity is the best suited condition. The last phase of maturity and ripening prevails for a period of about 90 days. In this phase, rapid accumulation of sugar as well as conversion of simple sugar to cane sugar takes place. A dry weather with good sunshine, warm days accelerate the process.

The crop is grown in more than 120 countries, of which, Brazil (420,121,000 MT), India (232,320,000 MT), China $(88,730,000$ MT), Thailand $(49,572,000$ MT), Pakistan (47,244,100 MT), Mexico (45,126,500 MT), Columbia $(39,849,240$ MT), Australia $(38,246,100$ MT), Philippines $(31,000,100 \mathrm{MT})$ and USA (25,803,960 MT) are the top ten countries in production (FAO 2005). Area wise, Brazil is the highest, i.e. 5.63 million ha, whereas, India's contribution is 4.0 million ha (FAOSTAT 2005). In production, Brazil still remains on the top with $33 \%$ of global sugar production followed India (23\%), China (7\%) and Pakistan (4\%) (FNP 2009). Worldwide sugarcane occupies an area of 20.42 million ha with a total production of 1328 million metric tons (FAOSTAT 2005).

In India, sugarcane occupy about 4.0 million hectare area and is produced in most of the states having the highest area of $47.05 \%$ in Uttar Pradesh followed by Maharashtra (17.52\%), Karnataka (7.76\%), Tamil Nadu (7.47), Gujarat (4.57\%) and Andhra Pradesh (3.76\%) contributing about $88 \%$ of the total area. The rest of the $12 \%$ area is shared by Bihar, Uttarakhand, Haryana, 
Madhya Pradesh, Chhattisgarh, Punjab etc. However, the yield of sugarcane per hectare is highest in Tamil Nadu, followed by West Bengal, Karnataka and Maharashtra (ICRISAT 2009). The average cane yield in India is about 70.0 tonnes per hectare while the sugar recovery is around 10.0 percent (IISR 2011).

Though, the cultivation of sugarcane is geographically restricted so as to climate, but its end products e.g, sugar and ethanol have a global increasing demand, therefore, it is very essential to look the cultivation, production and yield in this changing scenario of the climate. Sugarcane is very sensitive to the climate but also highly adoptive. Basically, it is a rain-fed crop and depends heavily on the amount and duration of precipitation, humidity, moisture content, temperature and soil condition (Gawander 2007). These factors are to some extent interrelated and the change in one normally affects the others. In recent years, both natural phenomena, i.e. variations in the earth's orbital characteristics, atmospheric carbon dioxide variations, volcanic eruptions and variations in solar output (Masih 2010): and, human activities, particularly, the rapid industrialization which resulted in increased emission of $\mathrm{CO}_{2}$, global warming, green house effect etc. (Segalstad 1996) have influenced the global climatic set-up. Therefore, it is a matter of concern on priority to study the effect of climatic change on various aspects of sugarcane.

\section{CLIMATE AND SOIL FOR SUGARCANE}

\section{Climate requirement}

Climate plays an important role in all the phases of the plant. Since, the plant stands in the field for 12-24 months, hence, goes through all possible limits of weather parameters i.e. rainfall, temperature, sunshine, humidity etc. All these parameters have a role in plant growth, sugar yield, quality and content of juice etc. For good growth of plant and high production, specific weather conditions with suitable parameter are required.

The crop is grown in the world from latitude $36.7^{\circ} \mathrm{N}$ to $31.0^{\circ} \mathrm{S}$ however, inhabits well in tropical region. In India, two distinct regions can be categorized for sugarcane cultivation, i.e. tropical and sub-tropical. The northern subtropical region experiences extreme summer temperatures as well as severe cold in winter, whereas, the tropical region south of Vindhyans, the temperature, like previous, shoots up to $47^{\circ} \mathrm{C}$ in comparatively prolonged summer season, however, winter is short and temperature is comparatively congenial. The cultivation is done right from Punjab and Haryana in the north to Tamil Nadu in the down south. It has wider adaptability and grows well where temperature ranges between $20-40^{\circ} \mathrm{C}$. It responds well to long period of sunlight (12 to 14 hours), high humidity (above $70 \%$ ) and high rainfall even up to $1500 \mathrm{~mm}$. If assured irrigation water is available, it can also be grown in areas where rainfall is low up to $500 \mathrm{~mm}$. As sugarcane crop remains in the field for more than 12 months, it withstands temperature variations of winter $\left(6-8^{\circ} \mathrm{C}\right)$ and summer $\left(40-42^{\circ} \mathrm{C}\right)$. The climatic factors required for the good growth of the plant is a matter of active research on global level which is basically necessitated to have a good crop in different regions having local variations in climatic set-up. Optimum climates required for cane development are as follows (Binbol et al. 2006, Gawander 2007):

Rainfall: Rainfall is an important factor for good growth of sugarcane. The plant requires optimum rains during the vegetative growth as it encourages rapid cane growth, cane elongation and internodes formation. During ripening period, the rainfall should be less in order to have good quality juice, less vegetative growth as well as reduction in the tissue moisture. Due to high rainfall, these conditions may be adverse. An average of $1200 \mathrm{~mm}$ evenly distributed rainfall in the range of $1100-1500 \mathrm{~mm}$ is optimum for higher yield. However, good productions are also being taken in the regions having a minimum of $600 \mathrm{~mm}$ and a maximum of $3000 \mathrm{~mm}$ rainfalls, which depends on adoptive measures, selection of varieties, farming methods (ICAR 2000).

Temperature: Temperature is equally important similar to the rainfall as it is closely related to the growth and productivity of the plant. Its optimum range varies for different phase of the plant which has a severe affect on good growth of plant and recovery of sugar. An optimum temperature for sprouting (germination) of stem cuttings is $32-38^{\circ} \mathrm{C}$ as it slows down below $25^{\circ} \mathrm{C}$, reaches plateau between $30-34^{\circ} \mathrm{C}$, and reduced above $35^{\circ} \mathrm{C}$, whereas, practically stops when the temperature is above $38^{\circ} \mathrm{C}$. Temperatures above $38^{\circ} \mathrm{C}$ reduce the rate of photosynthesis and increase respiration. During ripening period, a low temperature in the range of $12-14^{\circ} \mathrm{C}$ reduces vegetative growth rate and enrichment of sucrose in the cane (Fageria et al. 2010).

However, there is a control of cane variety, frequency and irrigation and other field practices on growth and production of cane as well as the yield of sugar. A minimum mean temperature of $20^{\circ} \mathrm{C}$ congenial during active growth phase. Temperatures both below $5^{\circ} \mathrm{C}$ and above $35^{\circ} \mathrm{C}$ are not suitable as previous may be harmful for young leaves and buds. In the later case of high temperature, rolling may occur irrespective of water supply. Further rise in temperature may enhance red rot disease. The durations of high and low temperature phases influence highly on sucrose accumulation. The adverse affect of high temperature is marked by reversion of sucrose into fructose and glucose. Enhanced photorespiration may reduce accumulation of sugar (Binbol et al. 2006; Gawander 2007):

Sunlight: Increase in leaf area index is rapid during 3rd to 5th month, coinciding the formative phase of the crop and attained its peak values during early grand growth phase. Light in terms of both duration and intensity is a necessary requirement of this $\mathrm{C} 4$ plant, which has a high capacity of photosynthesis as well as stabilization range. In general, high radiation favors high production of cane and good yield of sugar. On average 7-9 hours of bright sun light is optimum. In cloudy and short day's period, tillering may be adversely affected. Growth of stalk is also good during bright light with long duration (ICAR 2000; Fageria et al. 2010). The upper six leaves of the sugarcane crop canopy intercept $70 \%$ of the radiation which reduce the 
photosynthetic rate of the lower leaves due to mutual shading. Therefore, a care is to be taken for proper spacing during plantation. The areas with short growing period benefit from closer spacing to intercept higher amount of solar radiation and thus get higher yields however, with long growing season, wider spacing is suggested to avoid mutual shading and mortality of shoots (Legendre 1975).

The entire mechanism of sugarcane growth and formation of sugar depends on photosynthesis, for which sunlight is required. Like others, the growth of plant result from conservation of radiant energy from the sun into plants fibers and sugar. During the process, the first product of photosynthesis i.e. four carbon sugar $\left(\mathrm{C}_{4}\right)$ is fixed in the specialized cells of conductive tissue i.e. stem of the plant. The amount of carbon gain per day from photosynthesis is dependent on latitude and clouds covers. The previous, determines the intensities of radiation on horizontal surface and the later amount of radiation that reaches the surface. This plant thrives best under high solar insolation and temperature associates with lower latitudes (da Silva et al. 2008).

Relative humidity and wind have comparatively less control over plant, however, affect to a large extent in case of extremes. Up to $80-85 \%$ humidity and warm weather conditions favor the rapid growth of the cane. In ripening phase, a moderate humidity with limited water supply is favorable (SC 2012). Similarly, wind has no harm to plant until it reaches to a velocity capable of breakage of cane or damage to leaves. The high velocity may be harmful in initial stage of plant growth. The long duration high velocity wind will result to loss of moisture.

Broadly, two different sets of climatic parameters are required in the life cycle of the plant. Long duration of bright sunshine warm season with optimum rainfall high humidity in growing phase favors rapid growth of plant as well as cane length with good yield. The ripening season which is a phase of sugar storage needs clear sky without precipitation, warm days and dry weather conditions.

\section{Soil requirement}

Soils, forming the base of any of the crop, affect the productivity as per its inherent and dynamic proportions. It provides essential nutrients and water: and, holds the crop standing for months together. Broadly, it consists of thin layers, of which, the topmost is made up of soil panticks including animal and plant decay material. Numerous types of soils are reported world over, which depends upon physical, chemical and biological properties of the same. Since, soil is basically a weathered product: therefore, the host rock plays an important role in the composition of the soil. This specific composition makes the soil specific or suitable for a particular crop, for example, the alluvial soil of Punjab, Haryana, Uttar Pradesh and other adjoining area are highly fertile and rich in potassium making it highly suitable for sugarcane, rice, wheat etc. whereas, the black soil from Maharashtra and parts of Madhya Pradesh, Andhra Pradesh, a weathered product of basalt rich in iron, lime, calcium, magnesium provides good crops of cotton, sugarcane, groundnut, rice, wheat etc. The red soil is iron rich and more sandy due to high content of silica and ferromagnesium minerals in host crystalline rocks. It is good for groundnut, tobacco, potato, rice and sugarcane in the area of southern Karnataka, eastern Rajasthan, northeastern states, Maharashtra etc. However, all these soils are good for the sugarcane however, the cane variety matters. Certain other soil types i.e. lateritic soils, saline and alkaline soil, mountain soil, desert soil etc. are not suitable up to the required extent

A generalized idea about the soil conditions for the sugarcane is being summarized on the basis of information available on SC (2012). Sugarcane can be produced in all the types of soils, however, well drained loamy soil with a ph of 6.5-7.5 and adequate nutrients is considered to be the ideal. There should not be compaction in soil, as well as, it should be loose and friable with a minimum depth of 45 $\mathrm{cm}$, excluded with harmful soil. The plant can be well grown on higher soil, as well as, on heavy clays provided one has to opt for proper irrigation management.

A continuous monitoring of physical, chemical and biological conditions of the soil is required to ensure good cane growth, high yield and better quality of sugar. The bulk density and porosity of soil along with other significant physical parameters affects the root growth. A bulk density of $1.4 \mathrm{mg} / \mathrm{m}^{3}$ and porosity around $50 \%$ occupied by both air and water in equal proportions are highly favorable. Higher density hampers the proper spread and growth of roots. The plant has a capacity for deep roots up to $5 \mathrm{~m}$, hence, soil thickness along with its quality matters as deep soil have appreciable dry tolerance (Huang 2000).

The $\mathrm{pH}$ conditions other than the normal $(\mathrm{pH}$ 6.5-7.5) of soil may lead to alkaline or acidic nature. However, sugarcane can tolerate the $\mathrm{pH}$ range from 5.0-8.5 but requires lime or gypsum applications in more extreme conditions. Proper management of soil is required in case of saline soil i.e. dissolution, removal of salts by draining of water trough channels, organic manuring, mechanical treatments etc. There are certain plant varieties which can tolerate salinity up to certain limits, may be opted. The light textured soils bear poor water holding capacity which can be upgraded by addition of organic matter. Black soils usually have high water holding capacity but permeability is very less i.e. ill drained, hence, bad poor drainage (European Commission 2012).

Sugarcane is a management responsive crop: therefore, soil-plant relationship is to be monitored during all the phases of the plant. The condition of plant, as well as the soil, takes so many turns in entire period as the crop remains in the field for more than one year facing all the extremes of rainfall, temperature, sunlight, humidity etc. Therefore, it is recommended to maintain the congenial soil climate for good growth of plant by its proper management in various extreme conditions i.e. irrigations in dry period, maintaining drainage of excess water, pest control, weed control etc.

\section{EFFECT OF CLIMATE CHANGE ON SUGARCANE}

It general, agricultural production activities of all the sectors are the most sensitive and vulnerable to climate 
change (IPCC 1990, 2005). IPCC (2007) clearly reports that the climate change is real and the process is going on. Its impact will be disproportionately on developing countries threatening to undermine the achievement of the Millennium Development Goals, reduction of poverty and security of safeguard food. The climatic change is not only concerned with the crop production, instead, heavy impact on socio-economic set-up of a region, ultimately affecting the national economy. The change also poses significant challenges for the fair trade movement. There are evidences that most of the small farmers in Indian subcontinent, as well as others of Southeast Asia, are experiencing increased climate variability and change. It is expected that climate change will include more extreme events and slow onset impacts, such as changes in precipitation and temperature (Nelson et al. 2010). Climate change is likely to have mainly negative impacts upon agricultural production, food security and economic development, especially in developing countries (Hannah et al. 2005).

Sugarcane is also strongly influenced by the impacts of long-term climatic change as well as local weather and seasonal variations. The climate affects the growth and development of plants and may harm the crops. It also affects severely on the microorganisms related directly or indirectly for better growth and yield of the crop.

Rosegrant et al. (2008) identified potential direct effects of climate change on the agricultural systems which are as follows: (i) Seasonal changes in rainfall and temperature could impact agroclimatic conditions, altering growing seasons, planting and harvesting calendars, water availability, pest, weed and disease populations, etc. (ii) Transpiration, photosynthesis and biomass production is altered. (iii) Land suitability is altered. (iv) Increased $\mathrm{CO}_{2}$ levels lead to a positive growth response for a number of staples under controlled conditions, also known as the "carbon fertilization effect".

Certain model-based predictions of climate change on various regions of the globe have been made by Rosegrant et al. (2008), which are as follows: (i) Global models consistently highlight risk disparities between developed and developing countries. (ii) For temperature increases of only $1-2^{\circ} \mathrm{C}$, developing countries without adaptation will likely face a depression in major crop yields. (iii) In mid-to high latitudes, increases in temperature of $1-3^{\circ} \mathrm{C}$ can improve yields slightly, with negative yield effects if temperatures increase beyond this range. (iv) Stronger yield-depressing effects will occur in tropical and subtropical regions for all crops, which reflect a lower growing temperature threshold capacity in these areas. (v) Estimations predict that cereal imports will increase in developing countries by 10 to 40 percent by 2080 . (vi) Africa will become the region with the highest population of food insecure, accounting for up to 75 percent of the world total by 2080 .

Global warming, increase in the global temperatures, is one of the main factors affecting the climate in recent past, for which, the human activities play an important role (Nikolaos 2011). The global warming is result of an increase in the concentration of "greenhouse" gases, such as carbon dioxide, methane and nitrous oxide. The fossil fuel combustion along with land use change is the main reason for the global increase of carbon dioxide concentration, while agriculture for methane and nitrous oxide (Cerri et al. 2007). The increase in their concentrations will retain the radiations emitted by the earth's surface causing imbalance to the earth's thermal system. The changes in temperature, rainfall and solar radiation patterns due to global warming will affect the sugarcane production in both positive and negative ways. IPCC (2007) reported that the average global surface temperature has increased by $0.74 \pm 0.18^{\circ} \mathrm{C}$ in the last century and is projected to increase by another $1.1^{\circ} \mathrm{C}-6.0^{\circ} \mathrm{C}$ in this century: may be $6.0^{\circ} \mathrm{C}$ increase by the end of this century (Rahmstorf et al. 2007). The mean annual surface air temperature is likely to increase $\sim 4^{\circ} \mathrm{C}$ over India by the end of $21^{\text {st }}$ century (2071-2098). The temperature extended i.e. daily maximum and minimum temperatures may be intense which will be more intense in case of night time temperature (Kumar 2011). The role of temperature in cane development starts from the very beginning and continues up to later stage. It is directly linked with the growth of plant, photosynthesis as well as other biochemical processes including bud development (Gawander 2007). Photosynthesis efficiency of sugarcane increases in a linear manner with temperature in the range of $8^{\circ} \mathrm{C}$ to a maximum of $34^{\circ} \mathrm{C}$. Cool nights and early morning temperatures $14^{\circ} \mathrm{C}$ in winter and $20^{\circ} \mathrm{C}$ in summer significantly inhabit photosynthesis next day. The leaf growth is constrained at temperatures less than $14-19^{\circ} \mathrm{C}$. Cool night temperatures and sunny days slow down growth rates and carbon consumption, while photosynthesis may continue (Gawander 2007). Gbetibouo and Hassan (2005) employed a Ricardian model to measure the impact of climate change on South Africa's field crops including sugarcane. Their study reveals that the production of field crops in South Africa will be very sensitive to even marginal changes in temperature as the remaining range of tolerance to increased temperature is narrow compared to changes in precipitation. This result suggests developing the varieties of plant which should have more heat tolerance rather than draught and moving from rain fed to irrigated agriculture could be an effective adaptation option to reduce the harmful effects of climate change for the field crops. Gouvêa et al. (2009) made the future estimates of sugarcane yield in tropical southern Brazil for the years 2020, 2050 and 2080 on the basis of an agrometeorological model based on future A1B climatic scenarios and interpreted that increasingly higher temperatures will cause an increase of the potential productivity, since, this variable positively affects the efficiency of the photosynthetic processes of $\mathrm{C} 4$ plants. However, changes in solar radiation and rainfall will have less impact.

The rainfall is also a limiting factor. The countries depending more on rain-fed crops are experiencing an adverse effect the agricultural products including sugarcane because of the change in volume and spatial distribution of rains. A climatic prediction made for 2050 on Viti Levu Island, Fiji shows that the increases in rainfall during good years may offset the impacts of warmer temperatures, with 
little change in sugarcane production. However, a warmer and possibly drier climate could lead to more intense droughts during El Niño years in which the sugarcane will be heavily affected (World Bank 2004). The availability of water is more or less a dependable factor on climate which is well reflected in agricultural sectors. An increase in temperature will enhance the evaporation from soil, water and plant surfaces due to deficit of water in the atmosphere. There will be more demand of water to land ecosystems. Kimball et al. (2002) interpreted that elevated $\mathrm{CO}_{2}$ and temperatures will affect plant growth and water balance. Lawlor and Mitchell (1991) reported that the elevated atmospheric $\mathrm{CO}_{2}$ concentrations primarily enhance $\mathrm{CO}_{2}$ diffusion into the leaf and increase the photosynthetic rate of C3-plants over a wide range of radiation intensities. In India, monsoon is most active with a share of about $70 \%$ annual rain fall in the duration of June to September, i.e. summer monsoon or southwestern monsoon. However, south-eastern and northeastern regions are more affected by the northeastern monsoon for their agricultural produce. The high resolution regional climate precipitation model PRECIS, projects that summer monsoon in India may increase by $\sim 15^{0}$ to 2080 s relative to the base line period corresponding to 1970 s. The number of raining days may be non uniform over the country and spatial pattern may also differ. The intensity of rain fall on a raining day is likely to be higher in future (Kumar et al. 2011).

The sugarcane producing coastal belt areas are also vulnerable to climate change and a major loss is expected. Low lying areas will be submerged in this phase of sea level rise. Coastal erosion and inundation will be high.

\section{AGRONOMIC MEASURES}

Agronomy basically dealing with good production of any crop and yield starts from the very beginning. Sugarcane agronomy also starts with field preparation followed by seed selection, planting patterns, tillering, irrigation, manuring, weed and insect controls, irrigation management etc. These practices are though generalized, but also need certain specifications depending upon soil characteristics, field topography, cane variety, climatic conditions etc. The long standing crop should get the optimum condition for better growth in changing environmental and soil climate, hence, specific agronomic measures are required at different phases. Some of the agronomic measures required for the sugarcane are as follows:

\section{Field preparation and planting}

The field preparation starts with the cleaning of the field particularly, the left out of the previous crop. The seed bed for sugar should be free from the unwanted residue of the previous crop. Paddy happens to be a preceding crop in most of the Indian subcontinent which leave a lot of stubble and roots. A common practice to remove these is their collection followed by their burning and spreading the ash in the field which results in the change of soil texture and composition. The other affect of the paddy cultivation is the increase of soil moisture as the crop needs water and its local accumulation increases the moisture posing difficulty in ploughing. Hence, sufficient time of 1-2 weeks is required for decrease in soil moisture. A cross and deep ploughing for 2-3 times with sufficient organic manure provides good seed bed. Hard stubble of wheat, maize, sorghum should be taken out. In case of wheat as preceding crop, soil is not much deteriorated due to less moisture, hence, easy for preparation by simply collecting the residue and burning or removing the same. The cleaning is followed by ploughing which depends upon the soil conditions. Sometimes, mainly in the large forms, the transportation of crop by heavy vehicles make the soil compact and uneven which reduces the pore spaces to retain water and air, which is harmful for root development. It needs a proper tillering by disc harrows, tyned harrows or rotavator. However, 2-3 shallow and 1-2 deep ploughings are sufficient in order to maintain the soil density and moisture congenial for its proper aeration and softness. It is followed by the leveling of the ground for uniform crop stand and proper distribution of water. Organic manure may be added by last ploughing or in the later stage to improve soil fertility (ICRISAT 2009).

\section{Planting material}

The next step is the planting material and planting pattern with the selection of suitable variety of the cane. From a long time, scientists world over are involved in developing improved varieties to make the crop more productive and high yielding with respect to change in local setup of climate and soil. The selection of variety differs with the area, requirement, climatic conditions, soil types etc.: and, the information about the same is available locally in almost all the major sugarcane producing countries.

Cane setts, settlings and bud chips are planting material to raise the crop. The setts are the cut pieces of a healthy and disease free cane which bears 2-3 buds. In most of the countries three bud setts are used. To ensure a disease free material, a few treatments are recommended. Sugarcane Streak Mosaic Virus (SCSMV) and Sugarcane Mosaic Virus (SCMV) are two common viruses affecting the crop to considerable limit (Chatenet et al. 2005: Damayanti et al. 2010). Damayanti et al. (2011) concluded that the thermal inactivation point of SCSMV ranges between $55-60^{\circ} \mathrm{C}$, which is higher than the plant thermal death point. However, treatments at $53^{\circ} \mathrm{C}$ for ten minutes can reduce drastically the disease severity with maintaining $100 \%$ plant viability. Apart from this, simply soaking the cane water for 12-18 hours, mud or cow dung treatments are also applied for higher germinations. Treatment with specific chemicals i.e. $\mathrm{KMnO}_{4}, \mathrm{MgSO}_{4}$ or potassium ferrocyanide, ammonium sulphate, chlorohydrins, acetylene etc. are good for better germination and bud sprouting, whereas, prevention from fungal attack as well as insects can be made from Aretan and Benzene. Another vegetative material is the settlings that are cane setts having roots. It can be raised in the nursery as used in spaced transplanting, as well as, in plastic bags. The later has an advantage as the climatic conditions, soil conditions; 
nutrient supply can be regulated artificially: and over all, the transportation is easy. The other alternative is the bud chip which is excised auxiliary buds of cane stalk or, cutting of one bud from entire stem. It proved to be an alternate to reduce the mass and improve the quality of seed cane. These bud chips are less bulky, easily transportable and more economical seed material. The bud chip technology holds great promise in rapid multiplication of new cane varieties (Jain et al. 2010). This method, though have multifaceted advantages also bears certain drawbacks, e.g. poor survival conditions in the field, relatively low food reserves, limited survival etc. Food reserve and moisture in the bud chip depletes faster which results in poor sprouting which can be managed with suitable storage conditioned including low temperature. A study carried out for improvement of sprouting by soaking of pre-planting seed by growth-promoting chemicals viz, ethephon and calcium chloride helps in enhancing bud sprouting, root growth and plant vigor by altering some of the key biochemical attributes essential for the early growth and better establishment of bud chips under field conditions. Treated bud chips recorded higher bud sprouting, shoot height, root number, fresh weight of leaves, shoot and roots, and plant vigor index (Jain et al. 2011).

An ideal seed cane can be obtained from a seed crop of 7-8 months. Care should be taken to choose the seed free the diseases like red rot, wilt, smut, ratoon stunting disease etc. It should be healthy with high moisture content and nutrients and aerial roots and splits.

\section{Planting pattern}

Pattern of planting is a significant factor affecting the plant. Some of the commonly followed practices are flat beds, ridges and furrows, trench method, Rayungan method etc. The field method is adopted in the areas having low rain fall. It is a simple and cheep method mostly followed in northern and central India. Shallow furrows of 8-10 cm depth at the distance of $70-90 \mathrm{~cm}$ are made on flat seed bed. The setts with 3-buds are planted end to end in these furrows which are covered with the soil followed by leveling. Moisture content should be adequate at this time. The furrow planting is a common practice in the areas of northern and southern India having moderate rain fall and heavy soil with low drainage. V-shaped furrows of 15-20 $\mathrm{cm}$ depth are made at the intervals of $90 \mathrm{~cm}$. Addition of FYM, potassium and phosphate fertilizers, nutrient in the soil of the furrow may be done as per the requirement. The cane setts are planted in end-to-end manner and are covered by about $6 \mathrm{~cm}$ soil which leaves a furrow above the planted row. These furrows are watered in order to enhance soil moisture for good germination. The trench method is followed in coastal areas where strong winds prevail in the rainy season. This method prevents the crop from lodging. It is also known as 'Java method' as common in Java. Trenches of 20-25 cm depth are dug at the distance of $75-90 \mathrm{~cm}$. Suitable soil condition is made by addition and through mixing of fertilizers rich in sodium, potash and phosphate. Like previous, end to end pattern is also opted in this method. Chemical treatment to cane setts provides protection from soil born insects. Trenches are filled with the soil after planting. In Rayungan method, the seed stalk is topped off about two months before planting which results in the development of lateral shoots. Trenches having $30 \mathrm{~cm}$ depth and $90 \mathrm{~cm}$ lateral intervals are made and prepared by mixing of manure. Further digging and softening of soil up to the depth of about $15 \mathrm{~cm}$ is carried out and filled with same soil and fertilizer. Shaft of about $40-45 \mathrm{~cm}$ with 2-3 nodes are planted followed by irrigation. There are other methods of plantation like distance planting, bud transplantation, sprouting method, planting of uppermost nodes etc. which are more or less modifications of above mentioned methods suitable for specific region or climatic and soil conditions (IISR 2008).

Planting pattern has a direct bearing on the productivity and yield. An experiment conducted by Mahmood et al. (2007) to determine the effect of different planting patterns i.e. number of rows, spacing in between, width of the ditches, pit size etc. on the yield potential and juice quality of autumn planted sugarcane indicates that there were significant differences in the length, diameter and weight of individual cane. The data also shows high variation in cane yield as well as production of millable canes due to adoption of various planting patterns. Garside and Bell (2009) experimentally demonstrated that high density planting did not produce more cane or sugar yield at harvest than low-density planting regardless of location, crop duration, and water supply and soil health. In general, tiller survival, cane weight and yield are higher in wide row planting resulting to comparatively high produce of millable canes as well as longer duration and high-yielding nature of the same (Sundra 2002: IISR 2008: Kapur et al. 2011).

\section{Weed management}

Weeds are probably the single factor which can damage the crop productivity and yield up to the maximum limit. It can reduce the potential sugar yield by $25-90 \%$ along with other nutrients. In India, the common weed are Cynodon doctylon, Cyperus rotundus, Echinochloa spp, Saccharum sp. (narrow leaved), Chenopodium album, Solanum nigrum, Convolvulus arvensis, Trianthema sp. Digera arvensis, Anagallis arvensis, Fumania sp. (broad leaved) and Cynodon dactylon, Sorghum halepense, Panicum spp, Dactyloctenium aegyptium (grasses) etc. Since, the sugarcane is a long standing crop: therefore, it is affected by the different weeds in changing climatic conditions. The major reasons for easy susceptibility of the sugarcane are its planting pattern i.e. wide row gap: slow rate of plant growth as the germination phase is of 4-6 weeks followed by 8-10 weeks of full development of canopy: and, comparatively better water and nutrient conditions during plantation. These factors enhance the possibility of weed growth: however, the control of the same is essential for economical sugarcane production. It reduces the yields by competing for moisture, nutrients, and light during the growing season. Various growth phase of the plant are prone to specific weeds, however, the initial 4-6 months of growing phase of the plant need more care as negligence 
during this period will have an adverse affect on tiller growth as well as number and development of millable stalks (Chauhan and Srivastava 2002; Chattha et al. 2007).

The methods for weed control broadly consist of cultural, mechanical, chemical and integrated weed management practices. The cultural method includes the use of high tillering and fast growing cane varieties which reduce the time span of critical period of competition. Mulching of the trash, inter crop between the row space are also adopted. Mechanical and manual control includes the physical removal of weeds by bullock or tractor-drawn cultivators, harrows and rotavators or by manual labor implements like spade, hand hoe, etc. are very effective in early stages of crop growth. These practices are very effective, but now difficult to be opted because of so many reasons like, non availability of man power, high cost of labor, longer time span of operation etc, therefore, use of chemical methods i.e. use of herbicides are widely being followed. It provides an effective and long duration control as well as economical in a few cases. However, it is also true that chemical methods are only supplementary to cultural practices and as can possibly never replace the later. There are so many herbicides available in the market, however, prior to use, the opinion of expert is suggested for proper selection of herbicide, doses, methodology etc. Selective herbicides will invariably fail to kill some weeds and furthermore some herbicides will damage the crop because the protoplasm of desirable plants is similar to that of undesirable plants i.e. weeds. It follows that continuous and injudicious use of a particular selective herbicide will encourage a resistant type of weed to flourish and predominate (Stewart 1955).

The herbicides are specific for pre-emergence and postemergence varieties (see Mossler 2008; Odero and Dusky 2010; www.sugarcanecrop.com). Some common herbicides are (i) Atrazine-controls most annual grass and broadleaf weeds, (ii) 2,4-D-spiny amaranth, ragweed, morning glory, and many others, (iii) Ametryn-annual grass and broadleaf weed seedlings, especially effective against Alexander grass, (iv) Asulam- controls Alexander grass, broadleaf panicum, and other annual grasses but response is slow: it is applied only once per season, (v) Metribuzin-controls most annual grass and broadleaf weeds but is often mixed with atrazine or pendimethalin. It is applied at the time of planting or ratooning, but prior to weed emergence, (vi) Pendimethalin-control and time of application are same as previous and often mixed with the same, (vii) Halosulfuron- controls purple and yellow nutsedge as well as some broadleaf species and may be applied to any stage of sugarcane growth. Apart from these, Diuron, Alachlor, Trifluralin, Terbacil, Dalapan, Glyphosate, Paraquat are also in common use. Diuron is less common, though response well to broad leaves than grass. Trifluralin works on annual grasses and small seeded broadleaf weeds. Glyphosate is a broad-spectrum herbicide patented under the trade name Roundup. It is only effective on actively growing plants: it is not effective as a pre-emergence herbicide (WHO 1994; Duke and Powles 2008). Paraquat have an excellent control on annual weeds and can be used as an alternated to glyphosate. Integrated weed management is a combination of all the practices i.e. cultural, manual and chemical methods at proper time of the plant growth to get the maximum productivity and yield. A wise combination of various methods will also results to the best and economical way for controlling weed.

\section{Insect/pest control}

Insects and pests are equally dangerous if not controlled within time. Sugarcane is also very much susceptible to the same and may bear heavy loss due to rapid and enormous growth of the pests in comparatively short time depending upon climate, rain fall, temperature, as well as sufficient food material in the form of crop itself. More than 200 species of insects are known from India, however, a few are considered as most devastating. Some of the common insects of the sugarcane, its time of appearance and controlling measures are as follows:

Pyrilla perpusilla. It is a most destructive foliagesucking pest and causes heavy loss in cane yield and sugar recovery. It appears in the months of August-September after heavy rainfall casing high humidity. It attacks mainly on the leaves and leave sheath. Spray of chemicals is the only remedy. Planting in paired row method provides space for supervision and to undertake control measures (Paul 2007).

Termites. These are the underground insects attack the stalk used for the planting as well as shoots, canes. In initial phase, it finds the way from the cut ends of the seed and damage the soft tissue leading to low bud germination and replantation. These include Coptotermes heimi, Odontotermes assmuthi, $O$. obesus, $O$. wallonensis, Microtermes obesi and Trinervitermes biformis. They are most active under draught conditions, i.e. April-June and October, however, active in almost all the seasons. Farmers control termites by spraying pesticides over the stalks in the furrow during planting (Cheavegatti-Gianotto et al. 2011). The remedial measures include application of well rotten farmyard manure, removal of stubbles and debris of previous crop, addition of chemicals in the furrows during planting.

Borers. These are the insects which bore young shoots, canes and roots. Significant damage results from the sugarcane borer larvae tunneling within the stalk. This can cause a loss of stalk weight and sucrose yield. The borer's tunneling into the stalk allows points of entry for secondary invaders. If the tunneling is extensive, death of the terminal growing point of the plant may result. Weakened stalks are more subject to breaking and lodging (Cherry et al. 2001). The shoot borers (Chilo infuscatellus) attacks in the early phase during the months of plant growth i.e. April-June by entering laterally through the holes in the stalk and may even damage complete cane by upward or downward boring producing dead hearts. In early phase, it may damage the mother stem destroying entire stem. Plantation of early crop e.g. before mid March is suggested. Chemical treatment is effective. The internode borer (Chilo sacchariphagus) is one of the major pests of peninsular India (Gupta 1957) and is more active at the time or little after the internode formation, however effective during 
entire plant life (Ananthanarayana and Balasubramanian 1980). Due to infection, the internodes suffer reduction in length and girth causing considerable reduction in cane yield (David et al. 1979). It also deteriorates juice quality and reduces sucrose content (David and Ranganathan 1960). Immature internodes are normally attacked by fresh borers. The top shoot borer (Scirpophaga excerptalis) attack the youngest part of the plant top, and usually destroy the growing point. Young stalks die, whereas older stalks often die or produce side shoots and sucrose content is usually adversely affected (Sallam 2006). It attacks during March-October and is very serious during JulyAugust. The larvae usually penetrate along the midrib of the leaf into the heart of the plant. Larvae feed to tender leaves within the whorl and damage the growing points which turn dark. The other signs of attacks are shot holes in leaves, white or red streaks on the upper side of the mid rib and bunchy tops from July onwards. Collection and destroy of moth and egg clusters as well as integrated method of cultural and chemical methods are useful. The root borer (Emmalocera depressella) disconnects the conducting tissues of the root from the soil due to which the plant die. It also paves way for Ratoon Stunning Disease (RSD) (Gul 2007). Plants infested with E. depressella suffer dead hearts and general yellowing of the leaves and may result in poor tillering in mature plants. It infests sugarcane plants at all stages of development (Singh et al. 1996). Chemical and biological managements are effective if done at suitable time.

Black bug. This group of insects are mainly a problem of north Indian Sugarcane formers. It is most destructive for the ratoons. These include Blissus gibbus and Macropes excavates. Both nymphs and adult accumulate in the central whole of the cane shoot and suck the sap as a result the shoot turns pale, yellow in color with brown patches and sickly appearance. These consequently affect the chlorophyll content of the leaves, length, girth and ultimately weight of the stalk. The healthy stalk exhibited comparatively higher length as compared to infested stalk as well as loss in weight occurs. An increase in nitrogen content of infested leaves and decrease in chlorophyll content hampers the growth (Yadav 2003). Nymphs appear in March-April which is also a peak period of infection and from June to October, both nymph and adults are present together. The management needs both cultural and chemical methods. Burning of trash and leaves left behind the harvesting may be done in the months of March-April when the pest go through the early stage of its activity. Chemical method is the spray of specified insecticides. Nitrogen deficiency has been reported to invite black bug infestation in sugarcane ratoon crop (Jaipal 1991). Foliar fertilization of black bug infested cane crop with 2.5 percent urea at formative phase has shown to substantially reduce the young nymphal population. The incidence and intensity of black bug in ratoon crop may reduce from 5070 percent with a concomitant increase in shoot height simply by removal of plant crop residue and foliar $\mathrm{N}$ applications (Jaipal 2000).

Scale insect (Melanaspis sp.). It is probably a native to North India (Rao 1970) but prevails in other parts also. It is a post monsoon pest normally appears in 5-6 months old crop after formation of internodes. The symptom is the presence of approximately circular, smoky-brown or grayish-black scale covers on stems and leaf midribs (Agarwal et al. 1959). The scales are often so closely crowded that it is difficult to distinguish their individual shapes. Infested leaves may show drying of the tip and pale green to yellow coloration. Nodal region is more infested than internodal region. It thrives best between $24^{\circ} \mathrm{C}$ and $34^{\circ} \mathrm{C}$ and at high relative humidity: the traditional method of irrigation by flooding fields strongly favors survival of the pest (CPC 2012). Rao et al. (1991) found that a long dry period immediately after the rains favored a rapid build-up of $M$. glomerata populations. Wind is an important aid to the dispersal of the scale (Tripathi et al. 1985). The control of the pest is to be taken care from selection of setts by avoiding them from infested field. The setts may be treated with insecticide to ensure removal of infestation. Crop rotation with wheat is an effective measure (Varun et al. 1993). Detrashing and burning of the trash and other crop residue helps considerably. Spray of insecticide is quite effective controlling measure provided detrashing is carried out in combination with the pesticide application (Rao et al. 1976).

Mealy bug (Saccharicoccus sacchari). These are found in cluster, on the stalks under overlapping leaf sheaths, below the nodes and spread up and down to the other internodes and buds. The damage mainly occurs by sucking the cell sap, depriving plants of essential nutrients which may result to stunning, yellowing and thinning of the canes. It also plays an important role in virus transmission and the growth of sooty-mould fungus due to large amount of honeydew secreted by the insect (Eid et al. 2011). The pest populations grow fast under drought conditions and ants help in their dispersal to a large extent. Both nymphs and adults (female) suck the juice. The infested plants show a sickly appearance and look pale. Severe infestation may cause drying up of the leaves. Occasionally, cavity like depressions is formed on the internodes under the leafsheaths. Deterioration in juice quality and loss in sucrose content are the late results. Destroying of the affected leaves at harvest, selection of proper and healthy seed canes, spray of insecticides are the controlling measures. Spray material should be made in a way that it can trickle down the internodes into the underneath leaf-sheath in order to kill the nymphs.

White fly (Aleurolobus barodensis, Neomaskellia bergii). It is the most dreaded pest causing direct as well as independency for sucking cell sap from leaves. Population growth is high and reaches to maximum level under low lying, water logged and nitrogen deficient areas (Mann et al. 2006). It usually becomes active with the onset of monsoons having high humidity which favors its breeding. September-October is the period of maximum attack which gradually slows down in forthcoming days due to unfavorable climatic conditions. Both adult and the nymphs suck the sap from the leaves and turning them yellow. The adults are small pale yellow, ovate in outline with black and grey coating on the body. Nymphs reside underneath of the leaves and suck the cell sap. Due to the attack, cane 
juice becomes more watery. Reduction of sucrose and less recovery of sugar are other adverse affects. Loss can be minimized by avoiding ratoon in low lying areas, burn all the trash of the harvested crop, destruction of affected parts and foliar sprays

White grub (Holotrichia sp.). It is a problem of mainly tropical India, but the name 'white grub' is a collective term for various genus and species reported from sugarcane producing areas of the world. The pest life cycle consists of egg, larval instars, pupa and adult stages, of which, the late larval stage is the most damaging to sugarcane. It feeds on the root of the sugarcane and also damages the underground part of the stem by boring. The visible symptom can be seen in September with yellowing (chlorosis) of the leaves which is usually followed by stunted growth, dense browning, lodging, plant uprooting, and death in heavily infested areas. Symptoms may be seen as early as September. Damage is usually more severe in ratoon crops and is most evident around the edges of a field (Srikant and Singaravelu 2011). It thrives in moist sandy soil. The larval instars can survive for more than three months by remaining dormant inside the earthen cell. The management can be made by collection of beetles and destroying them either the same night or a night after first shower when the emergence is high. Cultural practice includes deep ploughing of field in the month of February well before summer showers. Flooding for 24-48 hours during pest activity period reduces grub population. Rotation of crop with paddy and sunflower also help to minimize the pest. Biological control is mostly selfsustaining as several vertebrates are natural enemy of the pest. A fungus Beauveria brongniartii infective to all stages of the white grub, penetrates the body wall of larva and multiply, thus killing the insect. The chemical method may be of little use, i.e. spray of insecticides immediately after the first summer shower (Srikant and Singaravelu 2011).

\section{Disease management}

There are about 50 diseases of sugarcane caused by fungal, bacterial, viral and phytoplasm pathogens (Vishwanathan and Padnabhan 2008). Fungal diseases include Red rot, Smut, Wilt, Eye spot, Yellow spot, Brown spot, Pine apple, Banded scletioal and Pokkah boeng, whereas Ratoon stunting, Leaf scald and Red stripe are mainly caused by bacteria. Viral and mycoplasmal diseases are Mosaic, Grassy shoot and Leaf yellow of sugarcane. Brief ideas about the symptom of important diseases are as follow:

Red rot. It is a fungal disease caused by Colletotrichum falcatum. The growth of this fungus is affected by temperature, $\mathrm{pH}$, nutrition and environmental conditions. It is one of main diseases of Indian subcontinent as well as other parts of the world. It can attack entire plant e.g. stalk, leaf, buds or roots however: the most amazing phase is its attack on stalk. The symptom depends on the susceptibility of the sugarcane variety, time of infection and the environment which may not be apparent in the initial phase but may be fatal in later stage. In the initial phase, the infected tissues show dull red coloration with whitish patches across the stalk. These white patches differentiate it from other stem rots. In resistant varieties, the infection is largely confined to the internodes. The typical stalk symptoms i.e. presence of white spots in otherwise rotten (dull red) internodal tissues and nodal rotting appear when the crop is at the fag end of the grand growth phase during August-September in subtropical India. In the early stages of infection, it is difficult to recognize the presence of the disease in the field, as the plant does not display any external symptom or distress. At a later stage, some discoloration of rind often becomes apparent when internal tissues have been badly damaged and are fully rotten. At the field level, this may be observed as the death of a few plants or clumps to the failure of entire crop (Duttamajumder 2008). Infected leaf shows small red marks on upper surface of the lamina and midrib. Due to this disease, retardation in the yield and deterioration occurs in juice quantity. The management includes selection of healthy setts treated with heat therapy: cultivate of resistant sugarcane varieties, burning of trash and other residue of the field, rotation of with paddy, onion, garlic, linseed and green manure crops etc. Precaution should be taken to control the spread of disease through water: hence, water of infected crop field is not to be allowed in other crop grown areas.

Sett rot or pine apple disease. It is caused by Ceratocystis paradoxa, both sett borne and soil borne. It infects in the primary phase of cultivation due to which the internal tissue of the setts turns red and black. The black coloration is due to production of fungal spores within the seed piece. Nodes act as partial barriers to the spread of rotting, but with susceptible varieties, entire seed pieces may become colonized by the fungus. The disease severely retards bud germination, shoot development and early shoot vigor. Pineapple disease can result in young plantcane crops having patchy, uneven appearance germination over large areas (Raid 1990). The disease is much prone in low lying areas and soils having ill drainage. It can be controlled by treating the setts by chemical fungicide before plantation (Vijaya et al. 2007).

Wilt disease. A fungal disease caused by Cephalosporium sacchari, spreads through setts and adversely affects the germination. Poor and weak quality germination ultimately affects the root development and cane formation. The symptoms are visible after 4-5 months of plantation during monsoon and post monsoon periods showing gradual withering. The affected tissue show reddish brown coloration in patches. The leaves turn yellow and dry up. The disease is controlled by selecting healthy, disease free seed setts after treatment with fungicide (Khan 2003; Gupta and Tripathi 2011).

Gummosis or gumming disease (Xanthomonas vasculorum). The symptoms are white leaf stripes with necrotic zones at leaf margins, extensive chlorosis of emerging leaves, vascular reddening and cavity formation in invaded stems, production of side shoots, rapid wilting and death of plants. Prolonged latent infection can occur, necessitating detection by isolation or sensitive molecular assays. The development and spread of disease includes xylem-invading pathogen, transmitted in cuttings, 
mechanically, and by wind-blown rain (Birch 2011). The control is mainly the precautions i.e. selection of disease free setts, cultivation of resistant varieties and destroying diseased canes.

Sugarcane smut. The causal organism of smut disease of sugarcane is Ustilago scitaminea, which occurs in most part of the world and spread by windblown spores, infested seed-cane and infested soil (Nzioki 2010). The diagnostic feature is the emergence of a whip which is gray to black, curved, pencil-thick growth which, emerges from the top of the affected cane plant. It arises from the terminal bud or from lateral shoots on infected stalks and may attain the length from a few centimeters to meter. It is composed partly of host plant tissue and partly of fungus tissue. The control measures are hot water treatment of seed canes, rouging out diseased plants, planting resistant or tolerant cultivars, and fungicides (Agnhotri 1983).

There are many other diseases of sugarcane which may affect to some extent in the growth and quality of juice, viz. ratoon stunting, yellow spot, red stripe, rust and genetic variegation of leaf and sheath. black rot, black stripe, brown rust, dry rot, leaf binding, leaf blast, leaf blight, leaf fleck, leaf scorch, leaf splitting, leaf yellows, mosaic range rust etc

\section{Soil and nutrient management}

Soil and nutrient management is the most emphasized aspects of the agro-technology to increase the crop production and sugar yield. Since, all the nutrient management practices are to be applied on the soil over which the crop is to be grown, therefore, the idea of soil condition, texture, composition etc. are the prerequisite. The soils of the area varies considerably, therefore, the agronomic methods varies from area to area. Land degradation in the tropics has mainly resulted from poor soil management practices. In Korea, despite choosing new sugarcane varieties with improved sugarcane and sugar yields, early maturity, resistance to pests and diseases, good milling qualities and adaptability to local growing conditions, the average yield was low as compared to previous years (Wawire 2006): for which, the decline of soil fertility resulting to depletion of essential nutrients was one of the main reason (Bell et al. 2001: Garside et al. 2003). The yield potentials and other characteristics are specific to a particular sugarcane variety. Soil is one of the main factors which influence the production according to its chemical composition particularly nitrogen and potassium which play a major role in physiology, growth and development (Malavolta 1994: Rice et al. 2002).

Both physical and chemical properties of the soil have an impact on the plant growth. Soil bulk density in the sugarcane field varies considerably as the crop is usually grown on low ridges i.e. rows with tractors and harvesters passing over the interrows making it compact. Because of the compaction, the soil strength gets increased but the porosity is reduced lowering the water intake capacity of topsoil (Srivastava 1984). The good soil structure, i.e. arrangement of soil particles having lots of pores and spaces is good for root development by allowing good drainage and aeration. Excessive cultivation, high irrigation may spoil this property of soil. The crusting of soil before development of crop canopy is a phenomenon of both rain fed and irrigated conditions. These crusts develop when the soil surface dries out after rainfall or irrigation. Physical disaggregation of soil particles occurs in response to the impact of raindrops, causing compaction of the surface layer which limits water penetration into the soil. Soil crusting is a precursor to soil loss through erosion and improving water intake rates (Meyer et al. 1996).

Acidity and alkalinity of the soil requires specific treatments. Acid soils are normally recorded in the areas of high rainfall areas and in the soils rich with organic matter. Under such environmental conditions, soils weather quickly and the basic cations like $\mathrm{Ca}, \mathrm{Mg}, \mathrm{K}$ are leached out from the soil profile, leaving behind more stable materials rich in iron and alumina oxides. This process makes soils acidic and generally devoid of nutrients. Accelerated acidification of soils under cultivation is most often due to the combined effect of oxidation of ammoniac fertilizers to nitric acid, mineralization of organic matter and leaching of basic cations from the soil. Because of acid soil, the growth of cane may not reach to the optimum: in addition, yield and quality of the juice are also adversely affected. High alumina level damages the root system: as a result, the roots tend to be shortened and swollen, having a stubby appearance. Management is possible by lime and dolomite applications. The solicity or soil salinity is also a common problem of sugarcane growing areas having low rain fall. It may be natural or secondary, developed due to irrigation however, in both cases, the plant is affected. In some areas, the cause of soil salination is due the development of high water tables, which allow capillary rise of saline ground water into the rooting depth of the crop. Occasionally, poor quality irrigation water may be another source of salts (Meyer et al. 1996). Various adverse affect reported are stunted growth, scorched tips and margins of leaves, poor root growth, poor cane quality, deterioration of juice quality etc.

The nutrient management is basically the maintenance of sound soil fertility conditions for the crop. The nutrient condition of the field which was good in the past may become poor in future due to many reasons including cultivation of crops without nutrient management. Each crop requires certain constituents which are taken from the soil resulting to reduce its quantity as per the previous level. Therefore, continuous cropping without proper management of nutrient will result to degradation of soil: hence, the nutrients management is required. Fertilizers are necessity for better management of the soil but at the same time its composition, quantity and time have an important role. Higher quantity of unwanted constituents may act as pollutant and harm the crop. Though, a lot of constituents are required for the sugarcane, however, the management of nitrogen, phosphorus and potassium needs special care for good crop.

Nitrogen is an essential part of all plants. Its deficiency in the soil is represented on sugarcane by short and thinner and shorter stalk, paleness of foliage, leaves turn black and die, blade turn light green to yellow, thin roots etc. It also influences the quality and quantity of juice. Phosphorus in 
low quantity reduces sprouting or no tillering, less elongation of stalk, red, greenish violet and purple colorations of leaf tips and margins, slender leaves, delay in canopy development etc. It is essential for cell division responsible for plant growth and also for better root development to support and develop healthy plant. It is a necessary constituent for formation of protein, photosynthesis and plant metabolism. Potassium helps in carbon assimilation and photosynthesis, in addition to providing resistance to sugarcane against pests and diseases. Symptoms of deficiency are yellow-orange coloration of leaf borders and tips, slender stalk. It is the most abundant cation of the cell sap. By acting mainly as an enzyme activator in plant metabolism, it is fundamental to the synthesis and translocation of sucrose from the leaves to the storage tissues in stalks. It also plays a significant role in controlling the hydration and osmotic concentration within the stomata guard cells (Ng 2002).

Sugarcane requires sulfur in relatively large amounts which is used for plant structure and growth. Plants take up sulfur as sulphate which is more mobile in soils. Other natural sources of sulfur are rainfall and irrigation. Calcium is essential for cane growth and for cell wall development. It is taken up as a positively charged cation from the soil solution. Magnesium is essential for plant photosynthesis as it is the main mineral constituent of chlorophyll. Sodium is required in very small amounts for the maintenance of plant water balance. Copper, zinc, iron, manganese, molybdenum, boron etc. are the micronutrients which are taken up by cane in much smaller quantities and are generally regulators of plant growth (Wood 2003). The deficiencies of micronutrients are also effective and their symptoms are visible either on leaves and stem in the form of odd appearance, different colorations, spots, necrotic leaves, thinning of stalks etc. It is advisable to contact the expert agronomist, because the identification of the deficiency of a particular micronutrient and their exact remedial measure is difficult for a common farmer.

The management starts with enhancement of the suitability of soil by adding organic manure i.e. farm yard manure (FYM), compost, dung etc. which improves the physical, chemical and biological properties of the soil. Apart from these, various other manures like, press mud, vermicompost, green manure can be made with little planning. The fertilizers provide a supplement to the soils depleting in one or more constituents. The requirement of the suitable fertilizer for a particular field can be known by the analysis of soil test result. At the same time, soil type, crop nutrient requirements, past fertilization practices and cropping history should also be taken into consideration. The traditional methods like mixing of fertilizer with soil, its application in the furrows followed by little irrigation are still widely used. It is also important to retain the nutrient in the field by avoiding the runoff and erosion for which soil and water conservation measures should be followed.

\section{Irrigation management}

Sugarcane is a high water requirement crop. The lack of water in soil cause the moisture stress which can ihfluence the crop from the very begning and up to the last. Reduction in the stalks elongation and leaves in the plant are the primary symptoms of water stress, whereas, the last phase of crop shows decrease in sucrose accumulation. Irrigation is therefore a major factor for growth of sugarcane which has been a matter of active research from the very begning and will probably continue with more quantum in future as the water is being expansive day by day, so as to the cost of irrigation.

In the present climatic conditions, it is evident that the rain fall is very erratic, unpredictable and uneven. Its stipulated duration is also shifting in some of the regions. In central India, 2-3 seasons of good rain fall is normally followed by a draught or low rainfall period. Since, the demand of sugarcane is high for the water, as the irrigation is required in almost all the phases of plant growth and cost of irrigation has also increased, therefore, the cost effective management is present need in almost all the sugarcane growing areas. Moreover, it also becomes necessary for the judicious use of the available water as its share for agriculture is also reduced due to high demand and consumption by domestic, private and public sectors in last 2-3 decades. In India, the present demand of irrigation water is between 543-557 billion cubic meter (BMC) as estimated by NCIWARD (1999) which may go to 628-807 BMC in the year 2050 and 826-852 BMC in the year 2065. However, it is expected that demand for water is likely to exceed the availability much before 2050 (Jain 2011).

Various traditional methods of irrigation followed for the crop are flood irrigation, large furrow system, serpentine method, alternate skip furrow method and contour furrows system which depends upon the availability of water, soil characteristics and topography of the area. In most of the practices, the water used for irrigation is often more than that of the requirement, and a certain amount of water go waste, particularly in the flood irrigation. Therefore, the drip irrigation is now a highly adopted technique. This technique is largely preferred in central India because of mainly low rainfall and high depth of water table. Further, it saves the water, reduces labor cost, save electricity and is suitable for almost all lands. Besides, free movement of pests and diseases as in case of flood management are automatically prohibited. Sprinklers are also being common.

The irrigation depends mainly upon the climatic condition of the region and type of soil, however, sowing pattern, type of manure and fertilizers are also the governing factors to some extent. The northern India, where the water table is comparatively low, most of the soil spread is alluvial and fertile, may need comparatively less number of irrigations. Water requirement is more in the areas having hot and dry winds. The method of sowing in trench form is little economical. The soil types and cane varieties also restricts the method and number of irrigations to be practiced for the crop. In all the cases, the irrigation is to be carried out to the extent preventing water-logged condition as it adversely affects the crop growth. 


\section{Biotechnological approaches}

Biotechnology plays a pivotal role for the improvement of Sugarcane varieties. Tiwari et al. (2010) suggested biotechnological approaches for sugarcane improvement in the following areas: (i) Cell and tissue culture for rapid propagation genetic transformation and molecular breeding, (ii) Introduction of novel genes into commercial cultivars, (iii) Molecular detection of sugarcane pathogens, (iv) Development of genetic maps using molecular marker technology, (v) Understanding the molecular basis of sucrose accumulation, (vi) Molecular testing of plants for clonal fidelity, (vii) Variety identification, and (viii) Molecular characterization of various traits.

Much focus had been made on development of transgenic plants and marker assisted breeding. Biotechnological strategies may improve a number of plant traits which may important for adapting to climate change including early vigor, water-use efficiency, nitrogen-use efficiency, water logging tolerance, frost resistance, heat tolerance, pest and disease resistance, and reduced dependence on low temperatures to trigger flowering or seed germination. Research is being conducted into developing molecular markers or GM varieties for these traits. The Genetically modified Sugarcane would really be the answer to cope with the challenges of Climate changes. Development of new stress tolerant, high yielding verities with the help of biotechnology may open up new avenues in sugarcane in sugarcane production.

\section{CONCLUSION}

Various climatic factors and agronomic measures required for better growth of sugarcane are specific in local set-up. The change in global climate is a matter of serious concern to sugarcane cultivators for sustainable development of the crop. A review of various climatic factors and agronomic measures strongly suggests for the adaptation of modern techniques being developed at regional level in most of the sugarcane producing areas. In the initial phase, both land preparation and planting material need a careful planning as the further growth of the crop entirely depends on the same. Land preparation requires a thorough study of the soil and climatic conditions of the region which may vary as per the temperature of the region, availability and intensity of rainfall and sun light. The selection of planting material is being suggested for those varieties which can sustain local climatic conditions as well as resist for pests and diseases. Since, sugarcane is a long standing crop and experiences severe changes in climate, biotic and abiotic factors, therefore, a regular care of soil and nutrient management, pest control, disease management and adequate irrigation are required. It is also advised to the cultivators to take suggestions of the experts to enhance the quality and production of the cane. Such expertises are made available locally by government at agriculture offices and research centers. Besides, all most all the agriculture universities, colleges and research institutes extend their cooperation to the cultivators for good development of crops including sugarcane. The same may be availed regularly to ensure good crop.

\section{REFERENCES}

Agarwal RA, Sharma DP, Kindaswamy PA. 1959. Feeding habit of sugarcane scale (Targionia glomerata Green). Curr Sci 28: 462-463.

Agnhotri VP. 1983. Diseases of sugarcane. Oxford and IBH Publishing Co.

Ananthanarayana K, Balasubramanian M. 1980. Distribution and intensity of internode borer of sugarcane, Chilo sacchariphagus indicus (K.) during different periods of plant growth. Proc Ann Conven Deccan Sugar Technol Assoc 30: 81-88.

Bell MJ, Garside AL, Halpin NV, Berthelsen JE. 2001. Yield response to breaking the sugarcane monoculture. Proc $10^{\text {th }}$ Aust Agron Conf, Australian Society of Agronomy.

Binbol NL, Adebayo A A, Kwon-Ndung EH. 2006. Influence of climatic factors on the growth and yield of sugar cane at Numan, Nigeria. Climate Research, 32, 247-252.

Birch RG. 2011. Xanthomonas albilineans and the antipathogenesis approach to disease control. Molecular Pl Pathol 2 (1): 1-11.

BoM [Bureau of Meteorology]. 2007. The greenhouse effect and climate change. Bureau of Meteorology Technical Report. Commonwealth of Australia, Melbourne.

Cerri CEP, Sparovek G, Bernoux M, Easterling WE, Melillo JM, Cerri CC. 2007. Tropical agriculture and global warming: impacts and mitigations options. Scientia Agricola 64: 83-99.

Chatenet M, Mazarin C, Girard JC, Fernandez E, Gargani D, Rao GP, Royer M, Lockhart B, Rott P. 2005. Detection of Sugarcane streak mosaic virus in sugarcane from several Asian countries. Sugar Cane Intl 23 (4): 12-15.

Chattha MU. Ali A. Bilal M. 2007. Influence of planting techniques on growth and yield of spring planted sugarcane (Saccharum officinarum L.). Pak J Agric Sci 44 (3): 452-455.

Chauhan RS. Srivastava TK. 2002. Influence of planting techniques on growth and yield of sugarcane. Ind. J. Weed Sci., 34(3-4): 318-319.

Cheavegatti-Gianotto A, de Abreu HM, Arruda P, et al. 2011. Sugarcane (Saccharum $x$ officinarum): A reference study for the regulation of genetically modified cultivars in Brazil. Trop P1 Biol 4 (1): 62-89.

Cherry RH, Schueneman TJ, Nuessly GS. 2001. Insect management in sugarcane. Entomology and Nematology Department Document ENY-406. University of Florida/ IFAS, Gainesville, FL.

Clark LG, Zhang W, Wendel JF. 1995. A phylogeny of the grass Family (Poaceae) based on ndhF sequence data. Syst Bot 20 (4): 436-460.

CPC [Crop Protection Compendium]. 2012. Melanaspis glomerata. CABI Intl. www.cabi.org/cpc.

da Silva FC, Diaz-Ambrona CGH, Buckeridge MS, Souza A. Barbieri V. Dourado Neto D. 2008. Sugarcane and climate change: Effects of $\mathrm{CO} 2$ on potential growth and development. Acta Horticulturae 331336

Damayanti TA, Putra LK, Giyanto. 2010. Hot water treatment of cuttingcane infected with Sugarcane streak mosaic virus (SCSMV). J Intl Soc Southeast Asian Agric Sci 16 (2): 17-25.

David H, Sithanantham S, Velayutham B. 1979. Some aspects of losses due to internode borer in sugarcane in Tamil Nadu. Proc Ann Conven Deccan Sugar Technol Assoc 29: 27-40.

David IL, Ranganathan V. 1960. Influence of internode borer on the quality of juice in sugarcane. Indian J Sugarcane Res Dev 4: 209-212.

Duke SO, Powles SB. 2008. Mini-review: Glyphosate: a once-in-acentury herbicide Pest Manag Sci 64:319-325.

Duttamajumder AK. 2008. Red rot of sugarcane. IISR, Lucknow Publication, India.

Eid MA, El-Shabrawy HA, Yakoub RS. 2011. An attempt to study the impact of Pink Mealybug infestation Saccharicoccus sacchari Ckll. on chemicals and allelochemicals of some sugarcane cultivars. Acad bJ Entomol 4 (1): 23-29.

European Commission. 2012. Guidelines on best practice to limit, mitigate or compensate soil sealing, SWD/2012/101 final.

Fageria NK. Virupax C. Baligar. Jones CA. 2010. Growth and mineral nutrition of field crop. $3^{\text {rd }}$ Ed. CRC Press, 437-456.

FAO 2005. Major food and agricultural commodities and major producers. FAO, Rome.

FAOSTAT. 2005. Primary Crops. FAO, Rome. 
FNP. 2009. AGRIANUAL 2009 - Anurio da Agricultura Brasileria, Sâo Paulo, P497.

Garside AL, Bell MJ. 2003. Management of legume residues to maximize the nitrogen benefits to the following sugarcane crop. Proceedings of International Society of Sugarcane Technologists 26: Sugarcane Agronomy.

Garside AL, Bell MJ. 2009. Row spacing and planting density effects on the growth and yield of sugarcane. 1. Responses in fumigated and non-fumigated soil. Crop Past Sci 60 (6): 532-543.

Gawander J. 2007. Impact of climate change on sugarcane production in Fiji. WMO Bull 56 (1): 34-39.

Gbetibouo GA, Hassan RM. 2005. Measuring the economic impact of climate change on major South African field crops: a Ricardian approach. Glob Planet Change 47: 143-152.

Gouvêa JRF, Sentelhas PC, Gazzola ST, Santos MC. 2009. Climate changes and technological advances: impacts on sugarcane productivity in tropical southern Brazil. Scientia Agricola 66 (5): $593-$ 605.

Gul K. 2007. Distribution and management of sugarcane borers in Peshawar Valley. [Dissertation]. KP Agricultural University, Peshawar.

Gupta BD. 1957. A note on the scientific and common names of sugarcane pests in India. Indian J Sugarcane Res Dev 2: 9-13.

Gupta SK. Tripathi SC. 2011. Fungitoxic activity of Solanum torvum against Fusarium sacchari. Plant Protect Sci 47: 83-91.

Hannah L, Lovejoy TE, Schneider SH. 2005. Biodiversity and climate change in context. In: Lovejoy TE, Hannah L. (eds.) Climate change and biodiversity. Yale University Press, New Haven.

Huang B. 2000. Role of root morphological and physiological characteristics in drought resistance of plants. In: Wilkinson, R. F (Ed.) Plant-Environment Interactions, Mercel Dekker, New York.

ICAR. 2000. (Indian Council of Agricultural Research). Handbook of Agriculture, $5^{\text {th }}$ ed., New Delhi.

ICRISAT. 2009. Training Manual on Sustainable Sugarcane Initiative: Improving Sugarcane Cultivation in India, An Initiative of ICRISATWWF Project, ICRISAT, Patancheru, Andhra Pradesh, India. 30P.

IISR. 2008. Annual Report, 2007-2008. Indian Institute of Sugarcane Research, Lucknow.

IISR. 2011. Vision 2030. Indian Institute of Sugarcane Research, Lucknow.

IPCC (Intergovernmental Panel on Climate Change). 1990. Scientific assessment of climate change. Working Group 1, World Metrologica Organization and United Nations Environmental Program, New York.

IPCC (Intergovernmental Panel on Climate Change). 2005. Climate Change 2005: The Science of Climate Change (including summary for Policy makers). Working Group 1, World Metrological Organization and United Nations Environmental Program, New York.

IPCC (Intergovernmental Panel on Climate Change). 2007. Climate Change 2007: The Physical Science Basis. Summary for Policy makers. Working Group I, World Metrological Organization and United Nations Environmental Program, New York.

Jain R, Solomon S, Shrivastava AK, Chandra A. 2010. Sugarcane bud chips: A promising seed material. Sugar Technol 12 (1): 67-69.

Jain R, Solomon S, Shrivastava AK, Chandra A. 2011. Effect of ethephon and calcium chloride on growth and biochemical attributes of sugarcane bud chips. Acta Physiol Plant 33: 905-910.

Jain SK. 2011. Population rise and growing water scarcity in India revised estimates and required initiatives. Curr Sci 101 (3): 271-276.

Jaipal S. 1991. Infestation and severity of damage by black bug, Cavelerius sweeti to shoots of nineteen sugarcane accessions and cultivars. Ann Appl Biol 118 (Suppl.) 12: 120-121.

Jaipal S. 2000. An IPM module for the management of major insect pests of sugarcane in Indian Subtropics. Sugar Technol 2 (3): 1-8.

Kapur R, Duttamajumder SK, Krishna Rao K. 2011. A breeder's perspective on the tiller dynamics in sugarcane. Curr Sci 100 (2): 183 189

Khan EA. 2003. Studies on weed control in sugarcane and allopathic effects on eucalyptus on field crops. Ph. D. thesis, Gomal University, Dera Ismail Khan.

Kimball BA, Kobayashi K, Bindi M. 2002. Responses of agricultural crops to free-air $\mathrm{CO}_{2}$ enrichment. Advan Agron 77: 293-368.

Kumar KK, Patwardhan SK, Kulkarni A, Kamla K, Rao KK, Jones R. 2011. Simulated projections for summer monsoon climate over India by a higher resolution regional climatic model (PRECIS). Curr Sci 101 (3): 312-326
Lawlor DW, Mitchell RAC. 1991. The effects of increasing CO2 on crop photosynthesis and productivity-a review of field studies. Plant Cell Environ 14: 807-818.

Mahmood A, Ishfaq M, Iqbal J, Hazir MS. 2007. Agronomic performance and juice quality of autumn planted sugarcane (Saccharum officinarum L.) as affected by flat, ditch and pit planting under different spatial arrangements. Institute J Agric Biol 9: 167-169.

Malavolta E. 1994. Nutrient and fertilizier management in sugarcane. International Potash Institute. Basel, Switzerland.

Mann RS, Suri KS, Sharma S. 2006. Population dynamics of insect pests of sugarcane in Punjab. Indian J Plant Protect 34 (2): 198-201.

Masih J. 2010. Causes and consequences of global climatic change. Arch Appl Sci Res 2 (2): 100-105.

Meyer JH, van Antwerpen ER, Meyer E. 1996. A review of soil degradation and management research under intensive sugarcane cropping. Proc South African Sugar Technol Assoc 70: 22-28.

Mossler M. 2008. Crop profile for sugarcane in Florida. www.ipmcenters.org

NCIWARD. 1999. Report of the National Commission for integrated Water Resources Development, Ministry of Water Resources, Government of India, New Delhi.

Nelson V, Morton J, Chancellor T, Burt P, Pound P. 2010. Climate change, agricultural adaptation and fair trade, identifying the challenges and opportunities. Natural Resources Institute, University of Greenwich

$\mathrm{Ng} \mathrm{KK} \mathrm{KF.} \mathrm{2002.} \mathrm{The} \mathrm{effects} \mathrm{of} \mathrm{potassium} \mathrm{on} \mathrm{growth,} \mathrm{development,} \mathrm{yield}$ and quality of sugarcane. In: Pasricha and Bansal (eds.). Potassium for Sustainable Crop Production: Potash Research Institute of India (PRII) and International Potash Institute (IPI), Horgen, Switzerland, 430-444.

Nikolaos C, Stott PA, Brown JS. 2011. The role of human activity in the recent warming of extremely warm daytime temperatures. J Climate 24 (7): 1922-1930.

Nzioki HS, Jamoza JE, Olweny CO, Rono JK. 2010. Characterization of physiologic races of sugarcane smut (Ustilago scitaminea) in Kenya. African J Microbiol Res 4 (16): 1694-1697.

Odero DC, Dusky JA. 2010. Weed management in Sugarcane. SS-AGR09. Agronomy Department, Florida Cooperative Extension Service, Institute of Food and Agricultural Sciences, University of Florida

Paul AVN. 2007. Insect pests and their management (online), Indian Agricultural Research Institute, New Delhi. nsdl.niscair.res.in/.../revised+insect+pest+and+their+management.pdf.

Rahmstorf S, Cazenave A, Church JA, Hansen JE, Keeling RF, Parker DE, Somerville RCJ. 2007. Recent climate observations compared to projections. Science 316: 709 .

Raid RN. 1990. Fungicidal control of pineapple disease of sugarcane. J Amer Soc Sugarcane Technol 10: 45-50.

Rao SV, Rao CS, Rao BHK. 1976. Mechanical and chemical control of sugarcane scale insect Melanaspis glomerata Green. Indian Sugar 26 (10): 689-693.

Rao VLVP, Rao NV, Rao SS. 1991. Influence of seasons on buildup of scale insect Melanaspis glomerata (G.), insecticidal performance and their effect on yield and quality in sugarcane. Indian J Plant Protect 19 (1): 17-22.

Rao VP. 1970. The sugarcane scale insect, Melanaspis glomerata Green. Indian Sugar 20: 279-282.

Rice RW, Gilbert RA, Lentini RS. 2002. Nutritional requirements for Florida sugarcane. Florida Cooperative Extension Service Publication SS -AGR - 228

Rosegrant MW, Ewing M, Yohe G, Burton I, Huq S, Valmonte-Santos R. 2008. Climate protection programme for developing countries. German Technical Cooperation Publication, Germany.

Sallam MS. 2006. A review of sugarcane stem borers and their natural enemies in Asia and Indian Ocean Island: an Australian perspective. Annales de la Societe Entomologique de France 42 (3-4): 263-283.

Sc. 2012. Sugarcane. www.sugarcanecrops.com. On Nov 2012

Segalstad TV. 1996. The distribution of $\mathrm{CO}_{2}$ between atmosphere, hydrosphere, and lithosphere; minimal influence from anthropogenic $\mathrm{CO}_{2}$ on the global "Greenhouse Effect". In Emsley, J. (Ed.): The Global Warming Debate. The Report of the European Science and Environment Forum. Bourne Press Ltd., Bournemouth, Dorset, U.K.

Singh M, Chhiliar BS, Madan YP. 1996. Biology of sugarcane root borer Emmalocera depressella Swinhoe. Indian Sugar 45: 12. 
Srikant J, Singaravelu B. 2011. White grub (Holotrichia serrata) as a pest of sugarcane and its management. Extension Publication 197, Sugarcane Breeding Institute, Coimbatore Publication, 1-5.

Srivastava AK. 1984. Soil compaction: a problem in sugarcane culture. Indian Sugar 34: 503-504.

Stewart MJ. 1955. A survey of chemical weed control in sugarcane. Proc $29^{\text {th }}$ Ann Congr South African Sugar Technol Assoc 29: 126-133.

Sundra B. 2002. Influence of varieties, seed and fertilizer rates and planting pattern on sugarcane (Saccharum officinarum) grown under wide row spacing. Indian Sugar 52 (5): 341-347

Tiwari AK, Bharti YP, Tripathi S, Mishra N, Lal M, Rao GP, Sharma PK, Sharma ML. 2010. Biotechnological approaches to improve sugarcane crop with special reference to disease resistance. Acta Phytopathol Entomol Hun 45: 235-249.

Tripathi N, Omkar, Shukla GS. 1985. Role of air currents in the dispersal of sugarcane scale insect crawlers. Agric Sci Digest, India 5 (3): 148 149.

Varun CL, Singh S, Singh HN. 1993. Cultural control of sugarcane scale insect (Melanaspis glomerata Green.) in Bhat soil. Indian J Entomol 55 (2): 219-220.
Vijaya HK, Kulkarni S, Yashoda R, Hedge YR. 2007. Chemical control of sett rot of sugarcane caused by Ceratocystis paradoxa. Karnataka J Agric Sci 20 (1): 62-64

Vishwanathan R, Padnabhan P. 2008. Handbook on sugarcane diseases and their management. Sugarcane Breeding Institute, Coimbatur Publication.

Wawire NW, Kahora FW, Wachira PM, Kipruto KB. 2006. Technology adoption study in the Kenya sugar industry. Kenya Sugar Res Found, Tech Bull 1: 51-77.

WHO. 1994. Glyphosate. World Health Orgnization, Geneva.

Wood AW, Schroeder BL, Stewart RL 2003. Soil-specific management guidelines for sugarcane production: Soil reference booklet for the Herbert District. CRC Sugar Technical Publication, CRC for Sustainable Production, Townsville.

World Bank. 2004. Cities, seas and storms: Managing Change in the Pacific Islands, Volume II Managing Pacific Towns. The World Bank, Washington D.C.

Yadav RA. 2003. Assessment of losses caused by black bug Cavelerius (Excavatus) sweeti to sugarcane in yield and quality parameters. Indian J Entomol 65 (3): 409-415 